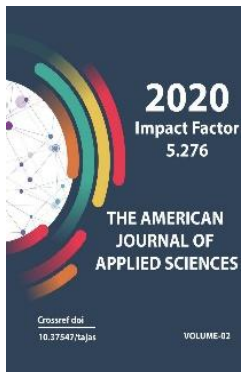

Journal Website: http://usajournalshub.c om/index,php/tajas

Copyright: Original content from this work may be used under the terms of the creative commons attributes 4.0 licence.

\section{The Penetration Of The Paper Into Uzbekistan And The} Samarkand Paper

\author{
Axmadaliyeva Nilufar Qobuljon Qizi \\ National Institute Of Fine Arts And Design Named After Kamoliddin Bekhzad \\ 3rd Stage Student Of The Faculty Of Fine Arts Of Khatutlik And Miniature, Tashkent City, \\ Uzbekistan
}

\title{
ABSTRACT
}

The main writing material that we all have today with the same application is of course this paper. The paper is one of the great discoveries made in the history of mankind, and is still maintaining its place as the main writing material. When and how was the paper made by whom? You can get a brief overview of a number of questions such as during the article.

\section{KEYWORDS}

Hin, light, supple, fluffy, surface is smooth, processing wood, cotton, or paper.

\section{INTRODUCTION}

Paper is a thin material, mainly made of vegetable fibers, and is made of a variety of wood pulp and vegetable pulp of one year, as well as wood mass. It is also obtained by processing wood, cotton, or paper. 
Advantage of paper: thin, light, supple, fluffy, surface is smooth, used on two sides, convenient for writing and drawing.

The disadvantage of paper: the water absorbs

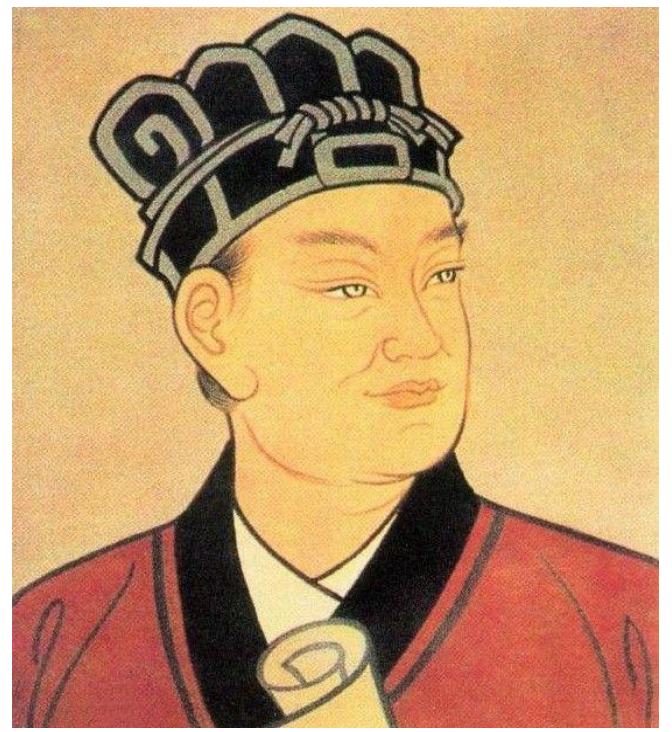

and burns quickly.

There are several interpretations on the history of the origin of the paper, according to widely known in the press, initially the paper was invented in ancient China in 105 BC by Tsai Lun, a consultant of the Kho Emperor. He saw a new kind of paper made from fishing nets. In terms of quality, it would not be left out of other writing materials, but in terms of cost was much cheaper. This important invention was of great importance not only for China, but for all mankind. For the first time in history, people got quality and cheap material for writing. For this reason, the name of Tsai Lun is also remembered among the great inventors of mankind.

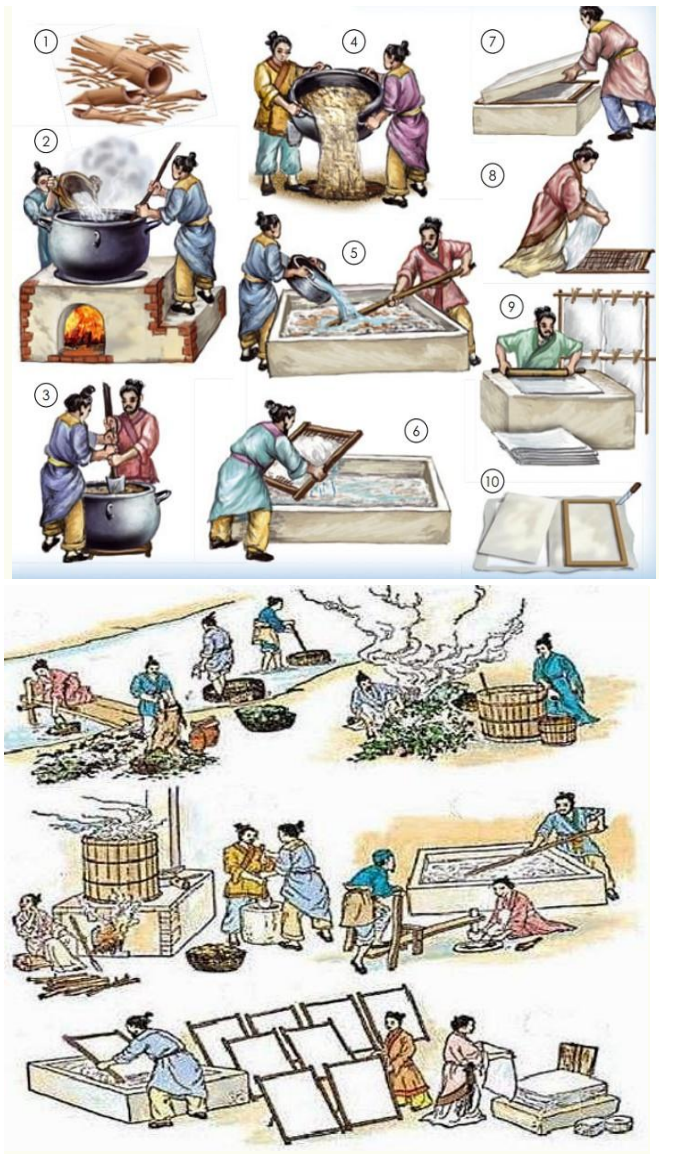

\section{MATERIALS AND METHODS}

The Chinese have conducted more recent research of paper making. Through experiments, methods of extracting paper from now-tree bark, cane or other fibrous plants were invented. Later, the Chinese mastered paper making at the level of art. For centuries, they kept the technique of making paper a secret from other peoples according to their custom. Over time, this mystery spreads the army to the countries of Korea and Japan. In 751-th year in the territory of Central Asia there will be a famous war between the Arab and Chinese troops with the Battle of Talas. In this battle, the Arabs will win. The captured Chinese soldiers show the Arabs the samples of paper that they will prepare in their homeland and offer their 
services in preparing it for the evazi of saving their lives. The reason for this event is the establishment of the first paper-making workshop in Samarkand by the Arabs.

There was a great demand for paper in the rapidly developing arab Caliphate. They introduced a few innovations in the light of paper-making. By the end of the VIII century, the city of Baghdad became one of the main centers for the abundant production, sale of paper.

In the IX century, paper began to be made on the Lands of North Africa, which belonged to the Arabs. By the $X$ century, the paper completely replaces the papyrus as a writing material. In this way, the paper is widely distributed to European countries.

When Samarkand paper, which has been famous for more than a century, has been prepared, it is possible to meet different information in different sources. But while it is not possible to determine which of the data is real, it is clear that the Samarkand khunarmans knew how to prepare quality paper for the V-VIII centuries.

In the Eastern world, Samarkand paper was used by the general public as Egyptian paper. An example of this is the writing of many Persian and Arabic works and ancient manuscripts on Samarkand paper, especially in the IX-X centuries.

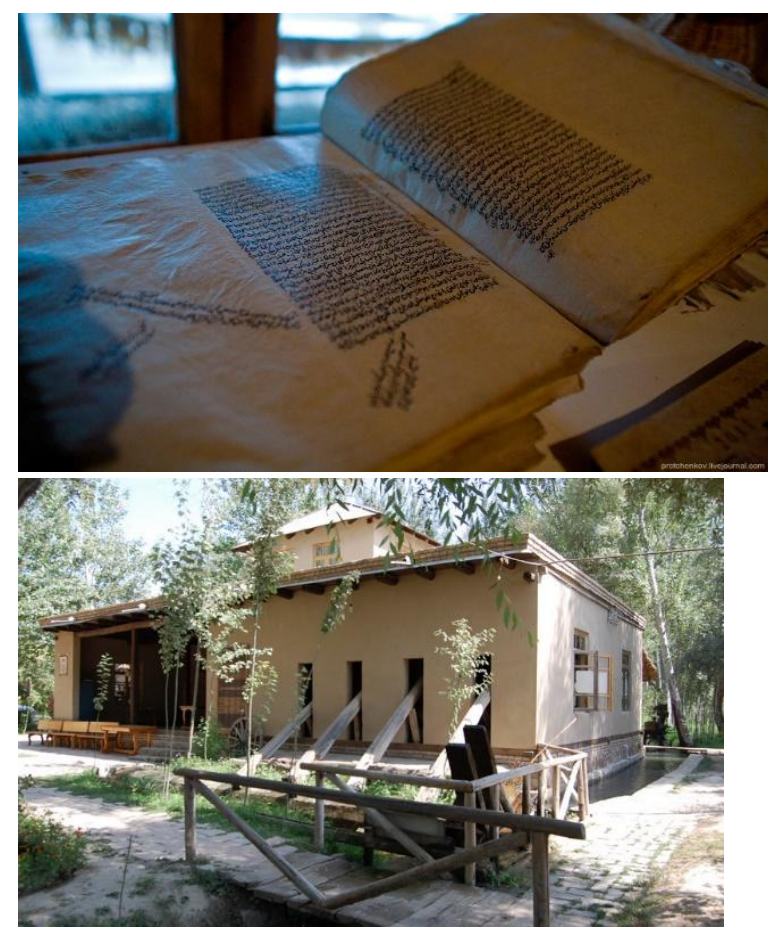

The color of the paper prepared in Samarkand is distinguished from the paper prepared in other places by a number of superior features, such as hungry bakuvian,baked, thin, sathida siyakhs tekkis gait, little absorption of siyakh. Samarkand paper was exported to European countries through the Silk Road.

According to information, at the beginning of the XVIII century around Samarkand there were 42 paper-making workshops. As a result of local urushlar,paper-making workshops were formed in the cities of Bukhara, Tashkent and Kokand.

About the Samarkand paper Shakh and poet Zahiriddin Muhammad Babur described in his famous book "Bournama" as follows: "the best paper in the world is prepared in the Konigili around the Siyab water of Samarkand". 


\section{DISCUSSION AND RESULTS}

After gaining independence, in order to restore the Samarkand paper, The Zarif Mukhtarov family organized a paper-making workshop on the fibers of the mulberry tree at the Konigil address near the city of Samarkand. Members of this workshop work hard to restore the method of preparation of famous Samarkand paper. Along with this, teachers of the National Institute of Fine Arts and design named after Kamollid Bekhzad are also engaged in the research of tinim bilmay. In particular, my teacher Mirkhamid Sobirov is doing great research in this regard and we are interested in teaching our students about it. From what and how is the paper made? They showed us a number of our questions not only in theory but also in a practical way. In the process, we saw that students also prepared our own papers by participating directly, and it was very interesting for us. Below I will briefly introduce the stages of preparation of Samarkand paper to your trust.

\section{Stages of preparation of Samarkand paper}

1. Peel the bark of the mulberry tree branch with a knife.

2. Separate the mucous part of the bark from the bark.

3. Fiber coat impregnation.

4. Boil the fiber porridge in the cauldron.

5. Kalt separate and grind the fibers.

6. Soak in water to make porridge.
7. Sipping in a sieve.

8. Separate the dressing paper in a sieve and dry in the shade.

9. Smooth the surface of the paper by rubbing it with a smooth stone.

According to information, today there are more than 600 types of paper. The most common types of paper used in them are the following:

1) Consulting paper that is the paper used for writing.

2) Vatman paper is thick and durable for image processing.

3) And Torshon paper is used mainly for color painting on water paints.

4) Melovannaya paper is glossy, high quality, baked paper is mainly used for printing bright colored advertising publications, such as magazine, catalog, booklet.

5) Shadow this type of paper is transparent and is used to copy the image.

6) Copy (copywriting) paper is thinner and on one side of it is covered with a special paint and is removed to leave a copy of the inscription and image.

7) Wrapping paper this type of paper is mainly used for wrapping products in trade.

8) Newspaper paper is mainly for the press.

9) Napkin paper this type of paper is a household paper.

10) Photo Paper is mainly used for making photos. 

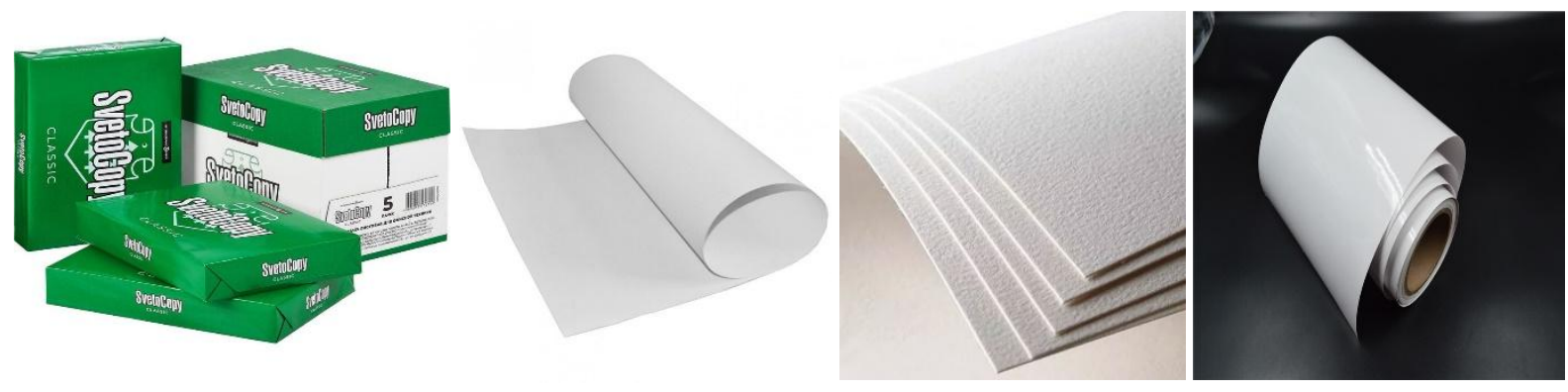

1

2

3

4

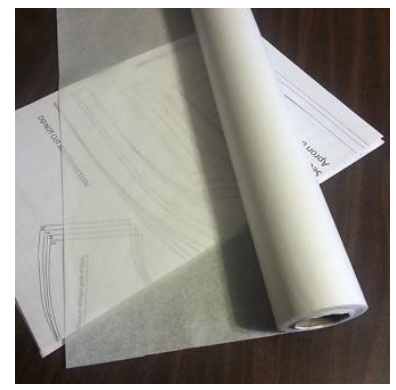

5

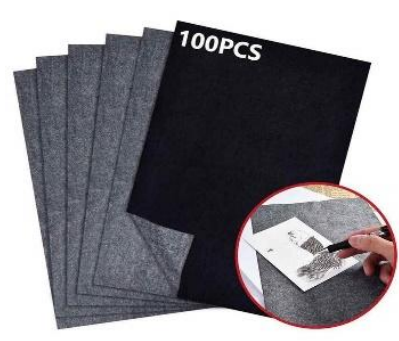

6

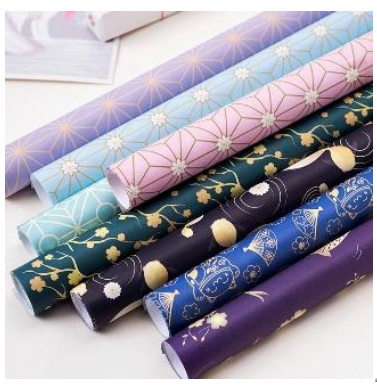

7

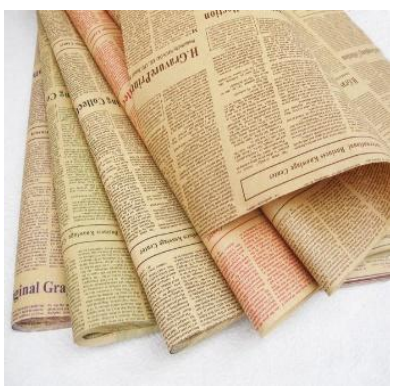

8

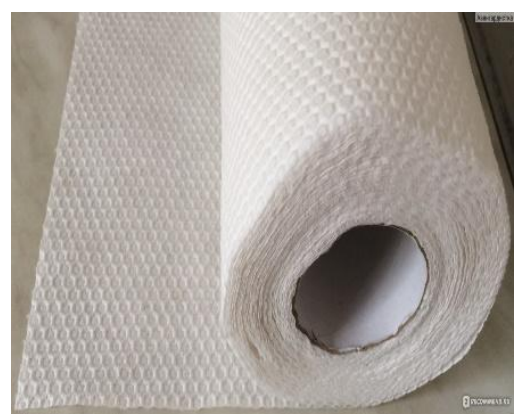

9

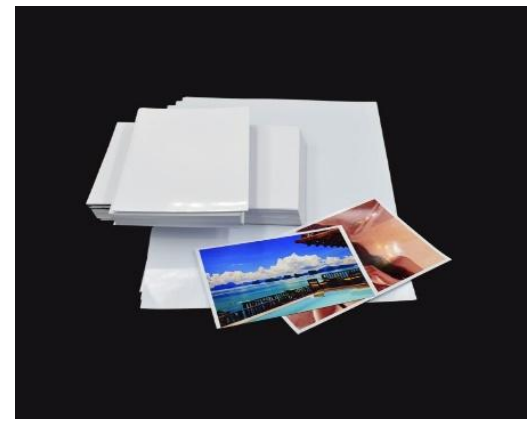

10

\section{CONCLUSION}

Today, in the age of developing techniques, it is difficult to imagine our life, without a phone, a computer and other gadgets in our hands. It is convenient to write, draw, communicate with them, and the problems will also be on son and fast, even at any point in the world it is possible to communicate with any person, knowing that their possibilities will be endless, as well as the role of paper, which is a great discovery of mankind, I think incomparably.

\section{REFERENCES}

1. Material science in the specialty 2018 year, 11-18p.

2. Karimov I.A. "The harmonious generation is the foundation of the development of Uzbekistan".Speech at the 9th session of the Oliy Majlis of the Republic of Uzbekistan, 199729 August. T: East, 1998. $-4-19 p$.

3. Karimov I.A. High spirituality is an invincible force. - T “ " Spirituality”, 2008. $-176 \mathrm{p}$. 
4. Karimov I.A. World financial and economic crisis, in the conditions of Uzbekistan ways and measures to eliminate it. - T: Uzbekistan, 2009. - 56p. $y$

5. Law of the Republic of Uzbekistan "on education". Harmonious generation -The foundation of Uzbekistan's development. T: East, 1998. -20 - 29p.

6. President of the Republic of Uzbekistan on May 21, 2004 "2004-2009 on the state nationwide program for the development of school education in the years 